\title{
Cardiac conduction disorders in six infants with "near-miss" sudden infant deaths
}

\author{
B R KEETON, E SOUTHALL, N RUTTER, R H ANDERSON, \\ E A SHINEBOURNE, D P SOUTHALL
}

identified and treated. The fourth child had the Wolff-ParkinsonWhite syndrome but was in sinus rhythm on admission (see case report).

The remaining two infants were already in hospital when they presented. One (case 5) had a fracture of the right humerus, and the other (case 6) had an upper respiratory tract infection. One of these infants (case 5) subsequently also developed a respiratory infection and was found collapsed in his cot in the ward. He was cyanosed and needed intubation and ventilation. There was also evidence of heart failure. The other infant (case 6) became apnoeic and cyanosed three hours after admission. Cardiac arrhythmias were identified on the electrocardiogram (ECG) at the time of collapse in both of these infants.

infant deaths. A further potential long-term effect these disorders is illustrated in one child in whom psychomotor retardation seemed to develop after an episode of cerebral hypoxia that was probably caused by an arrhythmia associated with the Wolff-ParkinsonWhite syndrome.

Cardiac conduction disorders may be detected by routine neonatal ECG screening, and it may therefore be appropriate to start prophylactic antiarrhythmic treatment in certain children before clinical signs develop.

\section{Introduction}

The connection between the sudden infant death syndrome and cardiac conduction disorders is contentious. ${ }^{1}$ Evidence about the possible association is rarely obtained because of the difficulty of designing prospective studies in this syndrome. Nevertheless, probably so-called "near-miss" sudden infant death is a comparable phenomenon. We recently identified conduction disorders in six infants who presented in this manner.

\section{Presentation of patients}

All six infants had been delivered normally at term and were of average birth weight. Three were bottle-fed and three breast-fed (see table). Two basic forms of presentation were encountered.

Four infants (cases 1-4) were found collapsed in their cots at home. Only one of these had previously been ill (case 3): he had had an episode of pallor in the second week of life. The infants were immediately referred to hospital and in three a cardiac arrhythmia was

Brompton Hospital, London

B R KEETON, MD, MRCP, senior registrar in paediatric cardiology

Torbay Hospital, Torbay

E SOUTHALL, MB, BS, senior house officer in paediatrics

Nottingham University, Nottingham

N RUTTER, MB, MRCP, lecturer in child health

Cardiothoracic Institute, London

E A SHINEBOURNE, MD, MRCP, senior lecturer and consultant paediatric cardiologist

R H ANDERSON, MD, MRCPATH, senior lecturer

Royal Crescent Cottage, Weymouth, Dorset

D P SOUTHALL, MB, MRCP, family practitioner
At 11 weeks this girl was found blue, cold, and collapsed in her cot. Respiration restarted after 10 minutes of mouth-to-mouth resuscitation by her mother. On admission the baby was pale, cyanosed, hypotonic, Primitive reflexes were absent and response to stimulation was poor. Dexamethasone and anticonvulsants were given and the fits were controlled. Investigations showed no hypoglycaemic, hypocalcaemic, or infective cause for her convulsions. The electroencephalogram (EEG) showed a generalised disturbance consistent with the effects of a previous episode of cerebral hypoxia. The ECG showed sinus rhythm with type A Wolff-Parkinson-White syndrome. Because of the probability that a primary arrhythmia might have caused the hypoxia she was given propranolol. The EEG reverted to normal over the next two months and at five months the ECG showed normal conduction. At 10 months there was evidence of psychomotor retardation with hypertonia and exaggerated reflexes. The ECG again showed WolffParkinson-White syndrome. At the time of writing she was still taking propranolol.

\section{Discussion}

The term near-miss sudden infant death has been used to describe the situation when previously well infants are found by their parents to be cyanosed or white and unconscious-in short, to be close to death. ${ }^{2}$ The six infants described here were all found in this condition. In each case the illness occurred suddenly and unexpectedly, and in different circumstances each of these infants might have died before diagnosis and treatment could be carried out. Had these children died necropsy might have shown evidence of congestive cardiac failure. Equally, in common with other examples of sudden infant death, ${ }^{3}$ it might not have shown an adequate cause for death.

In the first five infants it is reasonable to propose that a primary cardiac arrhythmia caused their acute severe illness. It is also probable that in case 6 a cardiac arrhythmia associated with the Wolff-Parkinson-White syndrome was responsible for the near fatal episode of cerebral hypoxia.

The two infants who showed severe bradycardias were in hospital for other reasons when the arrhythmias occurred. Both had evidence of respiratory tract infections. Respiratory syncytial virus was isolated from one. A viral myocarditis may have been present and caused these bradycardias. But no other ECG features of myocarditis were seen, and these episodes of bradycardia were similar to those identified in infants found to have sinoatrial block in the neonatal period (see accompanying paper). In contrast, these bradycardias may have reflected and convulsing. She had a regular heart rate of 150 beats/minute. 
Details of six infants with cardiac conduction disorders

\begin{tabular}{|c|c|c|c|c|c|c|}
\hline $\begin{array}{l}\text { Case } \\
\text { No }\end{array}$ & Sex & Feeding & $\begin{array}{l}\text { Birth } \\
\text { weight }(\mathrm{g})\end{array}$ & $\begin{array}{l}\text { Age at } \\
\text { presentation }\end{array}$ & ECG abnormality & Treatment \\
\hline $2^{*}$ & $\underset{\mathrm{F}}{\mathrm{M}}$ & $\begin{array}{l}\text { Breast } \\
\text { Breast }\end{array}$ & $\begin{array}{l}2840 \\
3460\end{array}$ & $\begin{array}{l}2 \text { weeks } \\
11 \text { days }\end{array}$ & $\begin{array}{l}\text { Supraventricular tachycardia } \\
\text { Supraventricular tachycardia with } \\
\text { varying P-R intervals, reciprocal } \\
\text { beats, and probable retrogradely } \\
\text { conducting accessory pathway }\end{array}$ & $\begin{array}{l}\text { Digoxin } \\
\text { Digoxin }\end{array}$ \\
\hline 3 & $\mathrm{~F}$ & Breast & 3430 & 3 weeks & $\begin{array}{l}\text { Supraventricular tachycardia and type } \\
\text { A Wolff-Parkinson-White syndrome }\end{array}$ & $\begin{array}{l}\text { Intravenous digoxin }(0.125 \mathrm{mg}) \text { with no } \\
\text { effect, then DC shock of } 7 \cdot 5 \text { joules; } \\
\text { recurrence treated with intravenous }\end{array}$ \\
\hline 4 & F & Ostermilk & 3120 & 11 weeks & Sinus rhythm, Wolff-Parkinson-White & Propranolol $5 \mathrm{mg}$ thrice daily \\
\hline $5+$ & M & SMA Milk & 2800 & 5 weeks & $\begin{array}{l}\text { Sinoatrial block with a slow junctional } \\
\text { escape rhythm of } 60 \text { beats } / \text { min }\end{array}$ & $\begin{array}{l}\text { Digoxin, frusemide; further episodes } \\
\text { treated with } 0.1 \mathrm{mg} \text { atropine }\end{array}$ \\
\hline 6 & $\mathrm{~F}$ & National Dried Milk & 2890 & 4 weeks & $\begin{array}{l}\text { Sinoatrial block with slow junctional } \\
\text { escape rhythm of } 70 \text { beats } / \text { min }\end{array}$ & $\begin{array}{l}\text { Further episodes treated with } 0.1 \mathrm{mg} \\
\text { atropine }\end{array}$ \\
\hline
\end{tabular}

* Irregular heart rate noted in utero and persisted until first stage of labour.

+ Respiratory syncytial virus isolated from nasopharyngeal aspirate.

disordered autonomic ${ }^{4}$ activity rather than primary cardiac conducting system disease.

The last infant in our series now has generalised hypertonia and severe psychomotor retardation. This infant was previously well and ischaemic brain damage probably followed an episode of low cardiac output as a result of a tachyarrhythmia, which was probably secondary to pre-excitation.

These cases suggest strongly that cardiac arrhythmias can cause certain unexplained sudden infant deaths. Had a screening ECG been performed in the neonatal period (see accompanying paper) these episodes may have been prevented. Our findings support our contention that further study is necessary to identify the conduction disorders in infancy. It will then be necessary to identify those who need treatment and the appropriate treatment.
We are indebted to Drs A Franklin, L Haas, R Jones, D Kennaird, A D Milner, and D G Vulliamy, who treated these children and gave their permission and help in the reporting of these case histories.

Requests for reprints should be addressed to: Dr D P Southall, Dorset County Hospital, Princes Street, Dorchester, Dorset DT1 1TS.

\section{References}

James, T N, Circulation, 1976, 53, 1.

2 Guilleminault, C, et al, Lancet, 1976, 1, 1326

${ }^{3}$ Emery, J L, in Recent Advances in Paediatrics, No 5, ed D Hull. London, Churchill Livingstone, 1976.

4 Schwartz, P J, American fournal of Medicine, 1976, 60, 167.

\title{
Comparison of the antilipolytic effect of metoprolol, acebutolol, and propranolol in man
}

\author{
RAYMOND J NEWMAN
}

British Medical fournal, 1977, 2, 601-603

\section{Summary}

Metoprolol and acebutolol, two supposedly cardioselective beta-adrenoceptor antagonists, were tested in 11 healthy men against propranolol, a non-selective drug, for their effect on plasma free fatty acid concentrations before and after insulin. The fasting concentrations of free fatty acid were significantly reduced after acebutolol and propranolol, and their return to normal after insulin was delayed. Metoprolol had no significant effect on free fatty acid levels either before or after insulin. Although both selective and non-selective beta-blocking drugs should be expected to delay the return of free fatty acid values to normal after insulin, in contrast to propranolol and acebutolol, metoprolol had no such effect.

This suggests that metoprolol may not be as effective as

St James's University Hospital, Leeds 9

RAYMOND J NEWMAN, BSC, MB, house physician (now senior house surgeon) the other two drugs in controlling lipid metabolism during long-term treatment with beta-adrenoceptor antagonists.

\section{Introduction}

Besides their circulatory actions, the beta-adrenoceptor antagonists in common use have several metabolic effects, ${ }^{12}$ including the inhibition of lipolysis. ${ }^{3}$ Newer beta-blocking drugs, however, are claimed to be cardioselective-that is, their action is maximal on cardiac beta-adrenoceptors and less so on beta-adrenoceptors in other tissues.

The study reported here was designed to compare the effect on lipolysis of propranolol, a non-selective beta-adrenoceptor antagonist, with that of metoprolol and acebutolol, two drugs generally considered to be cardioselective. Lipolysis was initiated by an insulin-induced fall in the concentration of circulating free fatty acid.

\section{Patients and methods}

Eleven healthy male medical students, aged $20-23$ years, with no history of diabetes mellitus, hyperlipaemia, ischaemic heart disease, 